\title{
Analisis Pengembangan Usaha Dengan Menggunakan Metode Capital Budgeting Pada Perusahaan Plywood Yang Mempunyai Bahan Baku Terbatas
}

\author{
ZAMRONI
}

Zamroni07@yahoo.com

\begin{abstract}
ABSTRAK
Jurnal ini membahas mengenai bagaimana perusahaan dapat menentukan kelayakan investasi suatu proyek dengan menggunakan Metode Capital Budgeting agar tidak mendapatkan kendala atau kerugian di masa mendatang. Tapi perusahaan PT XYZ mempunyai keterbatasan bahan baku sehingga dapat menghambat proses pengembangan investasi ini, tetapi dengan adanya keterbatasan ini PT XYZ berusaha untuk mengatasinya dengan jalan mempersiapkan lahan sebanyak 250 ha untuk menjadi lahan pembibitan yang akhirnya diharapkan dapat mengatasi masalah masalah bahan baku ini. Adapun manfaat dari penelitian ini yakni pertama, Tingkat kepercayaan diri PT XYZ untuk bisa menambah penjualan ke Indonesia Bagian Timur cukup tinggi, tapi harus dipastikan terlebih dahulu apakah pasar disana bisa menerima produk PT XYZ dan apakah dengan situasi ekonomi yang serba sulit pada saat ini penjualan PT XYZ akan tetap naik. Dikhawatirkan investasi yang dilakukan akan menjadi gagal karena tidak mempertimbangkan pasar di Indonesia Timur dan daya serap pasar. Kedua, PT XYZ diharapkan mencoba mencari alternatif lain sebagai bahan baku plywood karena pada tahun sebelum dipanennya hasil penanaman, perusahaan tetap membutuhkan log yang kondisinya pada saat ini sudah sulit ditemukan dan dengan harga yang mahal pula. Ketiga, Log sebagai bahan baku utama harus benar-benar dimanfaatkan secara maksimal dalam pemrosesan menjadi plywood karena dengan $30 \%$ persen terbuang dalam pemrosesan akan mengakibatkan besarnya biaya bahan baku yang terbuang percuma. Apabila ini diperhatikan akan menghemat biaya yang cukup besar dalam biaya perolehan bahan baku. Keempat, PT XYZ harus ketat dalam pengeluaran cash flownya terutama untuk biaya HPP seperti biaya sparepart, lem, bahan bakar dan bahan pembantu, biaya ini cukup besar dalam perhitungan biaya HPP, perusahaan diharapkan dapat mencari supplier baru yang bisa memberikan harga yang menarik dan dengan kualitas yang baik pula. Sedangkan biaya pemasaran, freight dan General Administrative juga harus di control agar bisa mengurangi biaya operasional, karena dibagian ini biasanya banyak biaya-biaya yang bisa dikurangi karena mengingat perusahaan baru dapat mengembalikan modal investasi selama 5 tahun mendatang.
\end{abstract}

Kata Kunci: Capital Budgeting, Proyeksi NPV, Discounted Cash Flow, IRR, Payback Period

\section{PENDAHULUAN}

Indonesia adalah negara yang mempunyai berbagai macam sumber daya alam, baik yang bisa diperbaharui ataupun tidak. Salah satu sumber daya alam yang dapat dimanfaatkan adalah kayu, yang dapat diolah menjadi berbagai macam kebutuhan baik kebutuhan primer ataupun sekunder. Salah satu kebutuhan primer yang membutuhkan bahan baku kayu adalah rumah, dalam pembangunan suatu rumah dibutuhkan kayu baik untuk membuat rangka rumah, kuda-kuda ataupun atap rumah. Sedangkan sebagai kebutuhan sekunder kayu dibutuhkan untuk membuat kertas. Oleh karena banyaknya pemanfaatan kayu untuk industri pada saat ini, maka kebutuhan akan kayu gelondongan semakin meningkat sehingga membuat kayu gelondongan menjadi susah didapat dan harganya mahal. Seperti kita ketahui kayu adalah sumber daya alam yang sulit diperbaharui kalaupun dapat diperbaharui diperlukan waktu yang cukup lama dan biaya yang tidak sedikit. Dimana saat ini industri kayu mendapatkan sorotan yang cukup tajam baik dari pemerintah, LSM ataupun masyarakat terkait dengan banyaknya bencana alam seperti banjir \& tanah longsor yang disebabkan oleh gundulnya hutan-hutan yang dikarenakan penebangan banyak pohon secara illegal dan tidak adanya reboisasi. Dan seiring dengan banyaknya kecaman ataupun sorotan tersebut, yang dilayangkan dari berbagai pihak turut 
mendorong pula jatuhnya industri kayu di Indonesia.

Berdasarkan info dari majalah bulanan APKINDO (Asosiasi Panel Kayu Indonesia) dinyatakan bahwa produk kayu Indonesia pada saat ini tidak mampu untuk bersaing dipasar dunia, ini disebabkan oleh karena kondisi mesin-mesin yang dimiliki hampir semua unit usaha sudah tua dan telah digunakan sekitar 20 tahun sehingga tidak lagi efisien dan mampu untuk menghasilkan produk unggul. Saat ini jumlah perusahaan kayu lapis yang masih aktif beroperasi hanya sebanyak 40 pabrik, dari total 120 pabrik yang terdaftar. Dari semua alasan menghentikan pengoperasian pabrik mengacu pada satu titik yaitu kesulitan financial untuk membeli bahan baku yaitu kayu gelondongan, karena harganya yang cukup mahal dan sulit untuk didapatkan, oleh karena itu para pengusaha dibidang kayu lapis oleh benar-benar mencari sumber alternative baru untuk mengatasi kelangkaan bahan baku, salah satunya dengan jalan melakukan pembibitan bahan baku secara pribadi yaitu dengan jalan membeli lahan dan menanaminya dengan pohon yang bisa cepat tumbuh dan bisa dipakai sebagai bahan baku tanpa harus mengandalkan kayu hutan. Salah satu tanaman yang sedang digalakkan untuk pembibitan yaitu kayu sengon dimana masa tumbuhnya relatif cepat dan mudah untuk pemeliharaannya.

Industri perkayuan merupakan industri yang harus mempunyai kecukupan modal yang cukup besar dikarenakan besarnya biaya investasi yang harus dikeluarkan untuk membangun suatu pabrik perkayuan serta mahalnya harga mesin-mesin produksinya, karena mesin-mesin produksi kayu mempunyai spesifikasi yang khas yang berbeda dengan industri lain serta dengan spesifikasi berbeda pula oleh karena itu mesin tersebut harus dipesan jauh-jauh hari karena tidak ada mesin pengolahan plywood yang tersedia dalam bentuk stok. Selain itu banyak biaya-biaya tidak terduga yang harus dikeluarkan perusahaan agar perusahaan bisa berjalan terus, karena seperti kita tahu pada saat ini industri perkayuan mendapatkan sorotan paling tajam atas terjadinya bencana alam dinegeri ini seperti banjir, tanah longsor serta kerusakan paru- paru dunia akibat penebangan liar. Dalam pengoperasian bisnis plywood terkadang biayabiaya non operasional cukup besar oleh karena itu apabila perusahaan mempunyai dana yang terbatas akan sulit untuk mengontrol alur cash flow dari perusahaannya tersebut. Oleh karena itu tindakan yang dilakukan oleh PT. XYZ untuk melakukan investasi pabrik baru adalah suatu investasi yang cukup beresiko dikarenakan adanya banyak sorotan dari berbagai pihak dan sulitnya mendapatkan bahan baku kayu gelondongan. Oleh karena itu penulis mencoba untuk melakukan penelitian atas investasi yang dilakukan oleh PT. XYZ apakah bisa layak untuk dilakukan, mengingat modal untuk investasi ini berasal seluruhnya dari modal internal perusahaan bukan pinjaman dari bank.

PT. XYZ merupakan salah satu perusahaan yang bergerak dalam industri perkayuan. Dimana PT. XYZ adalah salah satu anak perusahaan dari Holding yaitu ABC, yang membawahi kurang lebih 30 anak perusahaan yang tersebar di Tangerang, Jombang, Jambi, Banjarmasin, Palopo, dan beberapa daerah lain di Indonesia. Semua anak perusahaan dari $\mathrm{ABC}$ merupakan perusahaan yang bergerak dalam industri perkayuan dengan menghasilkan produk utama veneer dan plywood dengan berbagai macam variasi ukuran. Penjualan dari Holding ABC 30\% untuk pangsa luar negeri dimana negara tujuan utama yaitu Jepang, Korea dan Middle East sedangkan 70\% untuk memasok kebutuhan dalam negeri. Sedangkan PT. XYZ sendiri mempunyai pangsa pasar $95 \%$ pangsa pasar lokal meliputi wilayah Jakarta, Surabaya, Makassar serta beberapa kota besar di Indonesia, sedangkan untuk pangsa pasar internasional hanya berkisar $5 \%$. Pada saat ini PT. XYZ berusaha untuk mengembangakan lingkup penjualannya ke Indonesia Timur karena pada saat ini pangsa Indonesia bagian Tmur belumlah tergarap secara maksimal, sehingga membuat PT XYZ berusaha untuk mengembangkan bisnisnya dengan membuka pabrik baru untuk memenuhi kebutuhan didaerah Indonesia Bagian Timur tersebut.

Mengingat sedang lesunya ekonomi pada saat ini kita bisa melihat bahwa investasi yang dilakukan oleh PT. XYZ adalah cukup berani, dikarenakan 
lesunya pasar usaha baik dalam negeri ataupun luar negeri. Disini kita akan coba melihat kelayakan investasi pembuatan pabrik baru ini, mengingat sumber dana untuk investasi ini merupakan modal sendiri yang mana bisa mempengaruhi cash flow dari perusahaan, sehingga ditakutkan apabila investasi ini tidak berhasil akan menganggu siklus cash flow perusahaan, selain itu dalam pembangunan pabrik ini dibutuhkan dana yang tidaklah sedikit. Perusahaan juga harus melihat serta memprediksi faktor kendala yang akan terjadi dimasa depan dan membuat jalan keluar agar investasi tersebut tidak sia- sia dan menjadi beban dari perusahaan yang sudah ada.

Perusahaan melakukan investasi agar dapat mengembangkan usahanya menjadi lebih besar dan pada akhirnya memperoleh keuntungan yang besar pula. Pada kenyataannya belum tentu semua investasi yang dilakukan oleh perusahaan tersebut dapat menghasilkan hasil yang diharapkan. Analisa kuantitatif dalam pemantauan potensi usaha dapat dilakukan dengan pendekatan teori capital budgeting agar perusahaan tidak mengalami kerugian serta kesalahan akibat investasinya tersebut. Didalam dunia bisnis, perusahaan harus melakukan analisa investasi yang tepat dan dapat menjawab semua perubahan dan fluktuasi dalam berbagai variabel yang akan mempengaruhi hasil usaha mereka. Salah satunya dengan mengenali seluruh faktor resiko yang akan timbul baik resiko bisnis, resiko ketersediaan bahan baku ataupun resiko keuangan. Pada akhirnya dicari jalan keluar untuk menghindarinya atau paling tidak meminimalkan resiko-resiko tersebut agar tidak menimbulkan kerugian yang lebih besar.

\section{KAJIAN PUSTAKA DAN PENGEMBANGAN HIPOTESIS}

\section{Analisis Struktural Industri}

Ada lima elemen yang digunakan untuk melakukan analisis struktural industri, analisis ini sangat berguna untuk mengetahui kelebihan dan kekurangan yang dimiliki oleh perusahaan dan bisa untuk memperbaiki kinerjanya dimasa depan, berikut kelima analisis tersebut yang biasa disebut five forces dari Michael Porter:

\section{Tingkat persaingan dalam industri}

Persaingan dalam industri terjadi karena satu atau beberapa kompetitor merasakan adanya tekanan atau melihat adanya peluang untuk memperbaiki posisinya pada pasar dan dapat diamati dalam bentuk seperti kompetisi harga, perang promosi, pengenalan produk, dan meningkatkan layanan konsumen. Segala tindakan yang dilakukan oleh suatu perusahaan dapat memicu kompetitornya untuk melakukan tindakan antisipasi terhadap tindakan tersebut dalam industri. Salah satu bentuk persaingan dalam industri seperti kompetisi harga bersifat tidak stabil karena tidak dapat dipertahankan secara terus- menerus oleh perusahaan dimana salah satu penyebabnya adalah persaingan tersebut dapat mengancam profitabilitas perusahaan. Bentuk lainnya seperti perang promosi menyebabkan meningkatnya permintaan terhadap industri secara keseluruhan. Pada PT XYZ terjadi persaingan harga terutama untuk pangsa ekspor, disini sulit bagi PT XYZ untuk menyaingi harga dari para kompetitor terutama dari Malaysia dan China, kedua negara ini dapat menjual produk plywood lebih murah dikarenakan mereka mempunyai biaya operasi yang cukup murah dibandingkan di Indonesia, persaingan disini cukup memukul penjualan PT XYZ, apalagi disituasi ekonomi yang tidak menentu ini. Salah satu jalannya PT XYZ mencoba untuk membuka pangsa pasar baru di bagian Indonesia Timur agar PT XYZ bisa tetap survive dan berkembang karena potensi untuk pangsa ekspor sudah sulit untuk ditempuh.

\section{Ancaman dari pendatang baru}

Dalam suatu industri, pendatang baru akan berkeinginan meraih pasar dan menyebabkan bertambahnya kapasitas industri. Kehadiran pendatang baru tersebut menyebabkan adanya penurunan harga jual atau peningkatan biaya perusahaan dimana pada akhirnya akan menyebabkan adanya penurunan keuntungan perusahaan. Besarnya hambatan yang harus dihadapi dan rekasi yang mungkin timbul dari competitor yang sudah ada akan menentukan besarnya ancaman pendatang baru dalam suatu industri. Ancaman dari pendatang baru dikatakan rendah jika mereka mengalami hambatan yang besar 
dan atau mengalami reaksi yang keras dari perusahaan yang telah ada. Pada PT XYZ ancaman dari pendatang baru sangatlah kecil karena untuk memasuki industri bisnis ini tidaklah mudah dan harus mempunyai modal yang cukup besar. Selain itu kendala bahan baku adalah salah satu faktor utama yang memyebabkan orang enggan untuk masuk kedalam bisnis ini. Pada saat pendatang baru hampir bisa dikatakan tidak ada karena untuk industri yang sudah ada saja banyak perusahaan yang akhirnya tutup dikarenakan tidak mempunyai kecukupan modal untuk mengembangkan usahanya dan sulit untuk mendapatkan bahan baku.

\section{Ancaman dari produk substitusi}

Dalam suatu industri, setiap perusahaan akan mengalami kompetisi dengan perusahaan dalam industri lain yang memproduksi barang substitusi. Produk substitusi membatasi keuntungan potensial dengan membatasi kemungkinan harga tertinggi. Jika harga yang ditawarkan oleh produk substitusi semakin menarik maka ancaman adanya penurunan laba perusahaan semakain besar. Jika produk substitusi tersebut dapat digunakan tanpa menimbulkan biaya peralihan. Pada PT XYZ hampir bisa dikatakan tidak ada produk substitusinya oleh karena itu ancaman terhadap produks substitusi sangatlah rendah. Selain itu pencarian alternatif dari plywood masih berada pada tahap awal sehingga pengganti untuk plywood masih sangat kecil.

\section{Kekuatan tawar pembeli}

Dalam suatu industri, pembeli mempunyai kekuatan tawar terhadap industri sehingga memaksa agar industri menurunkan harga atau meminta industri untuk memberikan layanan tambahan kepada konsumen. Kedua hal tersebut dapat menurunkan keuntungan perusahaan. Kekuatan dari masing-masing kelompok konsumen pada suatu industri ditentukan oleh kondisi pasar dan tingkat kepentingan pembelian oleh kelompok konsumen tersebut relatif terhadap keseluruhan usahanya. Selain itu, jika produk dalam suatu industri relatif tidak memiliki diferensiasi, maka konsumen hanya akan mengeluarkan sedikit atau tidak sama sekali biaya tambahan yang dibutuhkan untuk peralihan konsumsi tersebut (switching cost). Kualitas produksi juga merupakan bahan pertimbangan dalam melakukan pembelian. Konsumen akan cenderung untuk memilih produk dengan kualitas tinggi. Pada PT XYZ kekuatan tawar pembeli sangatlah berpengaruh, karena pembeli bisa memilih produk dengan harga yang lebih miring, disini PT XYZ kurang mampu untuk bersaing dengan produk dari Malaysia dan China karena mereka menawarkan harga yang lebih kompetitif dari pada yang di tawarkan produk Indonesia. Sehingga akhirnya pembeli lebih memilih untuk membeli produk Malaysia tersebut.

\section{Kekuatan tawar pemasok}

Pemasok dapat menciptakan kekuatan tawar terhadap industri dengan ancaman untuk menaikkan harga atau mengurangi kualitas dari barang yang dibeli atau jasa yang ditawarkan. Kekuatan pemasok akan semakin besar seiring dengan besarnya jumlah pasokan terhadap keseluruhan industri. Selain itu, kekuatan pemasok juga dapat timbul ketika barang pasokan tidak mempunyai produk substitusinya. Pemasok yang kuat dapat mengurangi keuntungan yang diharapkan diraih oleh perusahaan yang tidak mampu mengantisipasi peningkatan harga pasokan tersebut. Pada PT XYZ kekuatan tawar pemasok cukup besar karena PT XYZ merupakan salah satu produsen plywood terbesar dan mempunyai variasi produk plywood. Tetapi didalam situasi ekonomi saat ini agak sulit bagi PT XYZ untuk menaikan harga, karena pada saat ini pembeli lebih condong untuk menahan pembeliannya.

\section{METODOLOGI PENELITIAN Populasi dan Sampel}

PT XYZ sudah berdiri hampir 40 tahun lamanya, dalam perjalanan industri ini sudah beberapa kali mengalami pasang surut sehingga PT $\mathrm{XYZ}$ sudah banyak belajar dari kesalahan atau kekurangan di masa lalu. Dengan Motto "Esok Maju” PT XYZ berusaha untuk menjadi perusahaan terdepan dan menjadi market leader di Indonesia. Tingkat pertumbuhan PT XYZ dipengaruhi dan mempengaruhi tingkat pertumbuhan ekonomi secara keseluruhan. Untuk mengetahui kekurangan dan kelebihan dari industri ini maka dilakukan beberapa analisis yaitu dengan memakai analisis struktural 
industri, analisis siklus industri dan analisis siklus hidup industri.

\section{Metode Analisis Data \\ Analisis Siklus Industri}

Sekitar 95\% pendapatan PT XYZ didapatkan dari penjualan plywood baik untuk pangsa dalam negeri ataupun luar negeri. Jadi tumbuh dan berkembangnya industri ini bergantung terhadap alam karena bahan baku dari plywood adalah log yang berasal dari alam. Hampir semua bangunan menggunakan plywood untuk pembangunannya oleh karena itu kebutuhan plywood didalam ataupun luar negeri pastilah selalu ada. Selain untuk bahan untuk pembuatan bangunan plywood bisa juga digunakan untuk membuat furniture, ubin ataupun pintu, oleh karena itu PT XYZ berusaha untuk mencari pasar baru sehingga kebutuhan masyarakat akan plywood dapat terpenuhi dan dapat meningkat laba serta kinerja PT XYZ. Plywood adalah salah satu komoditi yang menyumbang devisa bagi negara.

Agar industri ini bisa tetap berjalan perusahaan juga selalu mencari sumber- sumber baru untuk bahan baku, diantaranya dengan jalan membuka pabrik-pabrik satelit dimana didaerah itu banyak terdapat banyak bahan baku sehingga bisa mendukung ketersediaan bahan baku untuk pabik utama. Selain itu perusahaan juga berusaha untuk mempersiapkan kebutuhan bahan baku di masa depan dengan jalan membuka lahan baru sebesar 250 ha untuk ditanami bibit pohon yang dapat dipanen dalam waktu relatif singkat sehingga kebutuhan atas bahan baku dapat terpenuhi dan tidak terlalu mengandalkan dari hasil hutan.

\section{Analisis Siklus Hidup Industri}

Industri plywood mengalami booming pada era sebelum tahun 2000 karena pada saat itu ekspor plywood Indonesia cukup memegang peranan penting dikarenakan pada waktu itu Malaysia dan China belum masuk ke dalam salah satu negara pengekspor plywood. Pada tahun 1998 terjadi krisis moneter dimana nilai Rupiah terpuruk sehingga mengakibatkan banyak perusahaan yang mengalami kebangkrutan karena tidak sanggup mengatasi kerugian akibat melonjaknya nilai tukar Dollar terhadap Rupiah.

Tetapi pada waktu itu industri plywood mengalami peningkatan pendapatan dikarena selisih kurs tersebut karena pada waktu ekspor industri ini menjual dalam bentuk Dollar sedangkan biaya produksi dalam Rupiah sehingga industri ini mendapatkan keuntungan yang berlipat ganda. Selain itu pada saat itu birokrasi dari industri ini tidaklah sesulit seperti masa sekarang. Pada saat ini pangsa pasar plywood masih terbuka lebar dikarenakan pada saat ini hanya tinggal 40 Perusahaan aktif yang bergerak dalam bidang industri ini, sehingga kemungkinan untuk memperbesar pasar masih terbuka lebar. Karena pangsa yang masih besar ini membuat PT XYZ ingin mengembangkan usahanya dengan jalan menambah jumlah kapasitas produksi agar bisa memenuhi kebutuhan pasar, terutama pasar Indonesia Bagian Timur. Dari Analisis ini kita bisa mengambil kesimpulan bahwa industri plywood berada pada siklus ekspansi. Pada saat ini dibutuhkan penambahan kapasitas produksi dari pabrik dan investasi agar bisa menambah pangsa pasar. Pada tahap ini, industri plywood diharapkan masih bisa meningkatkan profitabilitasnya, dikarenakan masih ada pasar dan masih ada permintaan dari konsumen.

\section{Proyeksi Data Ekonomi dan Keuangan}

Dalam melakukan investasi perusahaan harus mempertimbangkan semua biaya-biaya yang akan mereka keluarkan dalam menjalankan proyek tersebut. Jangan sampai ada kesalahan dalam melakukan proyeksi atau perhitungan, apabila terjadi kesalahan perhitungan dikhawatirkan akan mengganggu kondisi cash flow dari perusahaan yang pada akhirnya proyek bisa tidak berjalan dan perusahaan mengalami kerugian.

\section{Asumsi Dasar proyek}

Dengan adanya peningkatan hasil penjualan dan prospek pasar yang dinilai cukup bagus, maka PT XYZ merencanakan untuk membuka pabrik baru dan menambah sejumlah mesin baru untuk meningkatkan jumlah produksi dan memperluas pangsa pasar. Pada saat ini PT XYZ hanya melakukan penjualan di pulau Jawa dan Sumatera 
saja, mengingat pangsa pasar diluar pulau itu masih cukup menjanjikan maka PT XYZ berusaha untuk memenuhi kebutuhan pasar tersebut.

Dengan adanya pembukaan pabrik baru dan penambahan mesin baru diharapkan PT XYZ mampu menambah cash inflownya, dan juga untuk memenuhi kewajiban-kewajiban pemberi kredit dan memperbaiki keuangan perusahaan. Selain itu dikarenakan biaya pembangunan pabrik ini berasal dari dana perusahaan tanpa pinjaman dari pihak lain, maka diharapkan pabrik baru ini dapat mempercepat pengembalian modal perusahaan yang dikeluarkan. Selain itu diharapkan keuntungan perusahaan akan bertambah sehingga bisa diharapkan bisa menjadi market leader dibidang plywood ini. Dalam melakukan investasi biasanya proyek membutuhkan asumsi dasar yang terdiri atas investasi awal, proyeksi arus kas selama masa proyek dan terminal cash flow. Disini akan dijabarkan satu persatu mengenai asumsi dasar tersebut:

\section{Investasi Awal}

Investasi awal, PT XYZ sudah menyiapkan sumber dana untuk investasi awal yang mana sumber dana tersebut merupakan dana yang sepenuhnya berasal dari perusahaan, tanpa pinjaman dari bank ataupun pihak lain. Dana yang dibutuhkan sebesar Rp 120 Milyar yang terdiri dari biaya pembangunan pabrik, biaya mesin, biaya konstruksi, biaya sewa alat berat biaya mess, biaya izin bangunan, dan lain- lain. Waktu yang dibutuhkan untuk mendesain, membangun hingga pabrik mulai beroperasi kurang lebih satu tahun.

Tabel 1 Perincian Biaya Pembangunan Pabrik

\begin{tabular}{|l|r|}
\hline \multicolumn{2}{|c|}{ Perincian Biaya Pembangunan Pabrik } \\
\hline Bangunan Pabrik & $16,500,000,000.00$ \\
Mesin - Mesin & $100,000,000,000.00$ \\
Konstruksi & $1,350,000,000.00$ \\
Sewa Alat Berat & $795,000,000.00$ \\
Mess Pabrik & $460,000,000.00$ \\
Upah Bangunan & $300,000,000.00$ \\
Bis Karyawan & $307,800,000.00$ \\
Pagar & $212,200,000.00$ \\
Izin Bangunan & $75,000,000.00$ \\
\hline TOTAL & $\mathbf{1 2 0 , 0 0 0 , 0 0 0 , 0 0 0 . 0 0}$ \\
\hline
\end{tabular}

Proyeksi Arus Kas Selama Masa Proyek
Permintaan konsumen, PT XYZ sudah menargetkan kenaikan permintaan konsumen naik berkisar sekitar 3\%-10\% pertahun bisa terlihat dari proyeksi penjualan PT XYZ. Permintaan ini realistik dikarenakan secara keseluruhan masyarakat sudah mengenal produk dari PT XYZ dan PT XYZ juga akan mulai memasarkan produknya ke area yang baru. Kenaikan berkisar 3\% - $10 \%$ ini dianggap wajar karena ada 3 faktor yang mendasar yakni Pertama, adanya penambahan pabrik dan mesin baru sehingga diharapkan kapasitas produksi meningkat sehingga penjualan juga akan bertambah. Kedua, Perluasan area pemasaran hingga Indonesia Timur yang sebelumnya hanya terfokus di Indonesia Barat saja, diharapkan menambah kontribusi penjualan dari plywood. Ketiga, PT XYZ akan segera memanen hasil penanaman sengonnya sehingga tidak akan kesulitan untuk mendapatkan bahan baku.

Biaya Variabel, peramalan biaya variabel dapat dilakukan dengan menilai kandungan biaya variabel dari produk-produk saingan. Biaya variabel juga akan dipengaruhi oleh inflasi dimasa depan sebagai contoh adalah biaya bahan baku yaitu log Biaya tetap, biaya tetap lebih mudah diramalkan daripada biaya variabel, sebagai contoh biaya tetap biaya upah, biaya sumbangan, biaya bahan bakar, dan lain-lain Usia proyek, PT XYZ menargetkan usia proyek selama 10 tahun dengan estimasi bahwa pabrik dan mesin yang ada mempunyai nilai bermanfaat selama 10 tahun, tetapi apabila dilakukan peremajaan dan pemeliharaan secara maksimal usia proyek bisa lebih panjang lagi Nilai tukar, nilai tukar pada proyek ini lebih tergantung kepada pembelian mesin-mesin serta pembelian sparepart, sedangkan untuk penjualan lokal semuanya dilakukan dalam Rupiah, sedangkan untuk penjualan ekspor penjualan dilakukan dalam USD dan freight juga dikenakan dalam bentuk USD Dikarenakan kurangnya supply bahan baku yaitu log maka perusahaan mempunyai alternatif untuk memenuhi bahan bakunya tersebut yaitu dengan jalan membeli lahan sebesar 250 ha dan ditanami dengan pohon sengon yang masa tumbuh hingga panen relatif sebentar yaitu 8 tahun. Proyek ini sudah berlangsung selama kurang lebih 2,5 tahun dan diharapkan bisa membantu kelangsungan 
pabrik. Pada saat ini sedikit sulit untuk mencari log kalaupun ada biasanya mempunyai harga yang cukup mahal.

Kebutuhan akan bahan baku selalu meningkat dari tahun ke tahun. Komposisi bahan baku yaitu $\log$ mencapai $35 \%-37 \%$ dari total keseluruhan biaya Harga Pokok Penjualan. Tetapi ditahun 2013 2015 terjadi penurunan pembelian log karena disaat ini perusahaan sudah memanen hasil penanaman lahan sebesar 250 ha, yang diperkirakan akan cukup untuk memenuhi kebutuhan selama beberapa tahun kedepan. Tetapi masih ada pembelian kayu jenis lain seperti Gmalina, Meranti dan Pinus yang belum bisa dikembangkan oleh perusahaan.

Dana Reboisasi memakan porsi 8\% setiap tahun tetapi bila perusahaan sudah memanen hasil penanaman lahan sebelumnya dana ini akan menurun, jumlah dana reboisasi yaitu hampir berkisar 25\% dari total HPP. Pada saat ini dana reboisasi yang dibayarkan lebih kepada penggantian biaya kayu yang sudah kita beli dari supplier kayu. Karena menurut peraturan Pemerintah kita harus membayar dana reboisasi setiap melakukan transaksi pembelian log.

Biaya sparepart dan bahan pembantu memakan porsi 6-7\% dari HPP sparepart disini merupakan biaya sparepart untuk mesin, kendaraan dan bahan pembantu merupakan biaya untuk memproduksi plywood.

Biaya lem dan bahan bakar memegang proporsi yang cukup besar juga yaitu sekitar 7-9\%, karena lem adalah bahan utama untuk perekat setiap lapisan diplywood sedangkan bahan bakar adalah sumber energi untuk pabrik oleh karena didaerah ini PLN belum mampu untuk mensupply listrik untuk pabrik sebesar PT XYZ.

Beban Operasi terdiri atas biaya freight dan biaya GA kedua komponen ini memakan 5-7\% dari total penjualan. Biaya freight lumayan besar karena letak pabrik PT XYZ yang agak terpencil sehingga agak sulit untuk sandar kapal besar, oleh karena itu banyak freight yang meminta charge yang cukup besar untuk mengangkut barang PT XYZ.

Untuk AMDAL PT XYZ berusaha untuk memenuhi semua ketentuan yang diberlakukan oleh Menteri Lingkungan Hidup agar tidak terjadi masalah dikemudian hari. Karena pada saat ini industri perkayuan sangat disorot pada setiap kejadian bencana alam seperti tanah longsor dan banjir. Oleh karena itu PT XYZ selalu berusaha untuk memenuhi ketentuan AMDAL yang berlaku

\section{Terminal Cash Flow}

Nilai sisa, nilai sisa setelah pajak dari proyek PT XYZ sulit diramalkan karena harus melihat seberapa besar nilai keberhasilan proyek tersebut. Setelah tahun ke 10 mesin-mesin sudah tidak mempunyai kemampuan untuk memproduksi secara maksimal, oleh karena itu mesin-mesin itu hanya bisa dipakai untuk 1-2 tahun kedepan dan dengan kondisi harus banyak dilakukan perawatan serta penggantian suku cadang, dan ini akan membutuhkan biaya yang tidak sedikit dan akan menggangu kinerja keuangan dari perusahaan. Sehingga dari pengalaman-pengalaman sebelumnya managemen biasanya mulai mengganti mesin-mesin tersebut dengan mesin baru dan menjual mesin lama tersebut dengan anggapan sebagai besi tua. Mesinmesin untuk industri plywood mempunyai spesifikasi yang unik yang mana kita harus memesan langsung dan sesuai dengan sepesifikasi yang kita inginkan, tidak ada dalam bentuk ready stock, oleh karena itu mesin-mesin ini tidak bisa dijual ke pabrik lainnya.

Metode penelitian yang digunakan dalam penulisan karya akhir ini: Observasi perusahaan dengan melihat industri PT. XYZ dan industri perkayuan secara keseluruhan dengan cara melakukan studi literature, studi data internal ataupun eksternal perusahaan. Membaca buku-buku, khususnya yang berhubungan dengan studi keuangan bagian capital budgeting agar dapat menghitung hasil dari Payback Period, Net Present Value, Internal Rate of Return dan Profitability Index. Mencari sumber-sumber lain baik dari internet, majalah, koran atau buku-buku yang berkaitan dengan jurnal.

\section{HASIL DAN PEMBAHASAN}

\section{Aspek Studi Kelayakan Proyek}

Dalam proyek pembangunan pabrik baru ini PT XYZ sudah terlebih dahulu memikirkan aspek studi kelayakan proyeknya tersebut, yaitu:

Dalam menanamkan investasi proyek ini terdapat manfaat financial bagi proyek ini ataupun bagi keseluruhan perusahaan. Diharapkan perusahaan akan terus meningkatkan pendapatannya 
dan dapat berlangsung selama mungkin. Sedangkan dari segi resiko perusahaan mempunyai resiko apabila pemasaran atas produk di Indonesia Timur mengalami kegagalan, tetapi sebelum masuk ke dalam pasar sudah dilakukan uji pasar oleh marketing PT. XYZ jadi kemungkinan kegagalan sudah diantisipasi sejak dini.

Manfaat ekonomis yang bisa diberikan oleh PT XYZ yaitu menambah lapangan kerja bagi masyarakat sekitar, karena daerah tempat PT XYZ beroperasi adalah daerah yang sedikit terpencil sehingga ekonomi masyarakat hanya bergerak didalam sektor pertanian dan perikanan. Dengan adanya pabrik didaerah ini dapat membantu menggiatkan ekonomi daerah tersebut dan membantu pemerintah untuk mengurangi pengangguran.

Sedangkan Manfaat sosial proyek bagi masyarakat sudah terasa karena berkurangnya pengangguran dan masyarakat juga bisa terbantu untuk menjual kayunya kepada PT XYZ sehingga ekonomi pedesaan dapat bergerak.

\section{Analisa Capital Budgeting}

\section{Analisa Weighted Average Cost of Capital (WACC)}

Metode Weighted Average Cost of Capital adalah metode perhitungan cost of capital secara simultan antara Cost of Debt (kd) dan Cost of Equity (ke). PT XYZ tidak mempergunakan dana pinjaman dari Bank oleh karena itu kd tidak diperhitungan dalam WACC, oleh karena itu dipergunakan CAPM. Dalam perhitungan (ke) risk free rate diambil dari yield Obligasi Ritel Indonesia (ORI 005) yang akan berakhir pada 15 September 2013 yaitu sebesar $11.45 \%$, sedangkan untuk risk premium berdasarkan Damodaran menyebutkan risk premium untuk Indonesia yaitu sebesar 6\% dan Beta diambil dari Beta perusahaan sejenis yaitu sebesar 0.91 .

\section{Rumus dari Weighted Average Cost of Capital}

$$
W A C C=\frac{E}{V} * k e+\frac{D}{V} * k d *(1-T C)
$$

Dikarenakan tidak menggunakan hutang maka perhitungan dilakukan dengan

CAPM: $\mathrm{ke}=0.1145+0.91(0.06)$

$\mathrm{ke}=16.91 \%$

$k e=r f+\beta(r m-r f)$
Tabel 2 WACC

\begin{tabular}{|l|r|}
\hline WACC & $\mathbf{1 6 . 9 1 \%}$ \\
\hline $\mathrm{Kd}$ (cost of debt) & - \\
\hline $\mathrm{Ke}($ cost of equity) & $16.91 \%$ \\
\hline $\mathrm{E} / \mathrm{V}(\%)$ & $100 \%$ \\
\hline $\mathrm{B} / \mathrm{V}(\%)$ & $0 \%$ \\
\hline
\end{tabular}

\section{Analisa Net Present Value (NPV)}

Nilai NPV didapat dengan mendiskontokan aliran kas menggunakan weighted average cost of capital (WACC) kemudian dikurangi dengan pengeluaran modal awal. Formula dari perhitungan NPV adalah sebagai berikut :

Rumus yang digunakan:

$N P V=\sum_{t=1}^{T} \frac{C_{t}}{(1+r)^{t}}-C_{0}$

Tabel 3 Net Present Value (NPV)

\begin{tabular}{|l|r|}
\hline \multicolumn{2}{|c|}{ NET PRESENT VALUE } \\
\hline \multicolumn{1}{|c|}{ Year } & \multicolumn{1}{c|}{ Cash Flow } \\
\hline Investment (Tahun 0) & $\mathbf{( 1 2 0 , 0 0 0 , 0 0 0 , 0 0 0 )}$ \\
Tahun 1 & $(31,652,781,000)$ \\
Tahun 2 & $36,956,021,600$ \\
Tahun 3 & $52,171,001,200$ \\
Tahun 4 & $42,883,110,000$ \\
Tahun 5 & $47,050,495,500$ \\
Tahun 6 & $45,171,196,500$ \\
Tahun 7 & $74,289,841,000$ \\
Tahun 8 & $64,512,125,500$ \\
Tahun 9 & $54,050,762,000$ \\
Tahun 10 & $49,732,476,000$ \\
WACC & $\mathbf{1 6 . 9 1 \%}$ \\
NPV & $\mathbf{4 1 , 8 4 8 , 1 9 6 , 0 9 3 . 5 1}$ \\
\hline
\end{tabular}

\section{Analisa Internal Rate of Return (IRR)}

Nilai IRR merefleksikan keuntungan yang didapat dari aliran kas suatu proyek. Nilai tersebut merupakan nilai intrinsik dari internal proyek dan tidak tergantung dengan variabel apapun selain aliran kas dari proyek. IRR adalah suku bunga yang membuat nilai NPV sama dengan nol. Disini kita bisa melihat bahwa nilai IRR dari dari PT XYZ adalah $23 \%$, dari pernyataan diatas bahwa apabila 
IRR aliran kas poyek lebih besar dari R WACC maka proyek tersebut dapat diterima. Disini kita ambil pembuktian 23\% > 16.91\% maka bisa diambil kesimpulan bahwa proyek ini dapat diterima.

Tabel 4 Internal Rate of Return (IRR)

\begin{tabular}{|l|r|}
\hline \multicolumn{2}{|c|}{ INTERNAL RATE OF RETURN } \\
\hline \multicolumn{1}{|c|}{ Year } & \multicolumn{1}{c|}{ Cash Flow } \\
\hline Investment (Tahun 0) & $\mathbf{( 1 2 0 , 0 0 0 , 0 0 0 , 0 0 0 )}$ \\
Tahun 1 & $(31,652,781,000)$ \\
Tahun 2 & $36,956,021,600$ \\
Tahun 3 & $52,171,001,200$ \\
Tahun 4 & $42,883,110,000$ \\
Tahun 5 & $47,050,495,500$ \\
Tahun 6 & $45,171,196,500$ \\
Tahun 7 & $74,289,841,000$ \\
Tahun 8 & $64,512,125,500$ \\
Tahun 9 & $54,050,762,000$ \\
Tahun 10 & $49,732,476,000$ \\
IRR & $\mathbf{2 3 \%}$ \\
\hline
\end{tabular}

\section{Analisa Payback Period (PP)}

Dengan melakukan perhitungan dengan metode Payback Period PT XYZ akan mencapai payback period yang diharapkan yaitu dalam waktu +/- 4 tahun 6 bulan. Ini merupakan proyek yang bisa dikatakan proyek yang bisa mengembalikan modal kerja dalam waktu yang tidak begitu lama sehingga bisa dikatakan proyek ini merupakan proyek yang menjanjikan. Dengan Investasi awal sebesar Rp, 120,000,000,000 (Seratus Dua Puluh Milyar) PT XYZ akan mendapatkan kembali modalnya dan menghasilkan keuntungan ditahun ke 4.

Hasil perhitungan payback period bisa terlihat pada table berikut ini:

Tabel 5 Payback Period (PP)

\begin{tabular}{|l|r|}
\hline \multicolumn{2}{|c|}{ PAYBACK PERIOD } \\
\hline Tahun 0 (Initial Investment) & $\mathbf{( 1 2 0 , 0 0 0 , 0 0 0 , 0 0 0 . 0 0 )}$ \\
Tahun 1 & $(31,652,781,000.00)$ \\
Tahun 2 & $36,956,021,600.00$ \\
Tahun 3 & $52,171,001,200.00$
\end{tabular}

\begin{tabular}{|l|r|} 
Tahun 4 & $42,883,110,000.00$ \\
Tahun 5 & $47,050,495,500.00$ \\
Total Cash Flow: & $147,407,847,300.00$ \\
\hline Payback Period = & 4 tahun 6 bulan \\
\hline
\end{tabular}

\section{Profitability Index (PI)}

Metode valuasi digunakan untuk melihat ratio dari present value dari harapan cash flow dimasa yang akan datang setelah intial investment dibagi dengan jumlah dari initial investment tersebut. Sebuah proyek bisa diterima apabila nilai profitability indexnya lebih besar dari 1 (satu), semakin tinggi nilai PI maka semakin tinggi nilai rankingnya apabila dibandingkan dengan proyek lainnya.

Didalam proyek hasil profitability Index adalah 1.35 berarti ini menandakan proyek dapat diterima karena profitability indexnya lebih dari 1 yaitu $1.35(\mathrm{PI}>1)$

Tabel 6 Profitability Index

\begin{tabular}{|l|c|}
\hline \multicolumn{2}{|c|}{ PROFITABILITY INDEX } \\
\hline \multicolumn{1}{|c|}{ Year } & Cash Flow \\
\hline Present Value & \\
Tahun 1 & $\mathbf{( 2 7 , 0 7 4 , 4 8 5 , 5 0 2 )}$ \\
Tahun 2 & $27,038,456,197$ \\
Tahun 3 & $32,649,323,700$ \\
Tahun 4 & $22,955,123,413$ \\
Tahun 5 & $21,542,985,984$ \\
Tahun 6 & $17,690,969,399$ \\
Tahun 7 & $24,886,728,233$ \\
Tahun 8 & $18,485,366,557$ \\
Tahun 9 & $13,247,589,929$ \\
Tahun 10 & $10,426,138,184$ \\
Initial investment & $\mathbf{( 1 2 0 , 0 0 0 , 0 0 0 , 0 0 0 )}$ \\
\hline \multicolumn{2}{|c|}{ PI } \\
\hline
\end{tabular}

\section{KESIMPULAN}

Dari data-data yang sudah diuraikan diatas maka dapat ditarik kesimpulan sebagai berikut: Pertama, Krisis global yang melanda dunia pada saat ini juga mempengaruhi dari tingkat penjualan ekspor plywood dikarenakan permintaan yang cukup berkurang dari luar negeri. Selain itu faktor persaingan dengan Negara Malaysia dan China cukup ketat dikarenakan mereka dapat menjual 
plywood dengan harga yang lebih kompetitif dan kualitas yang lebih baik. Dengan adanya kelesuan pada pangsa pasar luar negeri PT XYZ coba mengembangkan penjualannya kepangsa dalam negeri yaitu dengan jalan membuka pasar baru di Indonesia Bagian Timur, dikarenakan selama ini pasar plywood PT XYZ hanya untuk Indonesia Bagian Barat. Kedua, Dengan adanya penambahan pabrik diharapkan penjualan PT XYZ dapat meningkat, dikarenakan pada tahun-tahun ini kondisi ekonomi baik lokal maupun global sudah berangsur pulih dan bisa menguasai pangsa pasar plywood di Indonesia. Ketiga, Berdasarkan analisa Five Forces dapat terlihat bahwa perusahaan mempunyai tingkat persaingan yang cukup rendah untuk pangsa pasar lokal karena banyaknya perusahaan yang sejenis yang sudah berhenti beroperasi sedangkan untuk pangsa ekspor perusahaan mempunyai pesaing yang cukup berat yaitu Malaysia dan China karena mereka dapat menjual produk dengan harga yang lebih murah dan juga dengan kualitas yang baik. Belum adanya produk subtitusi membuat konsumen sukar untuk berpaling dan konsumen khususnya lokal tidak dapat memainkan harga tetapi yang mempunyai kekuatan dalam segi harga adalah produsen. Keempat, Dengan reboisasi diharapkan PT XYZ sudah dapat memanen hasil penanaman bibit pohon sengon sebagai bahan baku industri, sehingga diharapkan dapat membantu PT XYZ untuk tidak tergantung lagi terhadap pasokan log dari hasil hutan. Kelima, Proyeksi penjualan sebesar 3\%-10\% adalah suatu sikap optimis dimana perusahaan sudah membuktikan bahwa pendapatan mereka selalu naik setiap tahunnya, dengan bertambahnya pangsa pasar yang baru diharapkan ada penambahan pendapatan bagi keseluruhan perusahaan. Keenam, Proyeksi penjualan selama 10 tahun didasarkan kepada umur mesin dari Plywood tersebut dikarenakan mesin-mesin plywood mempunyai masa waktu untuk bekerja hanya selama 10 tahun, setelah itu harus dilakukan penggantian mesin baru. Dari proyeksi cash flow dapat terlihat penjualan akan meningkat dan tersedia pasar baru yang dapat menambah pendapatan selain itu karena berkurangnya kompetisi di industri plywood yang disebabkan banyaknya pabrik yang sudah tutup. Ketujuh, Dengan analisa Capital Budgeting maka proyek penambahan pabrik baru ini dinilai sangat feasible mengingat nilai NPV yang positif. Dan juga IRRnya sebesar $23 \%$ dan masa pengembalian modal hanya dalam waktu +/- 4 tahun serta profitability index yang mencapai 1.35 .

\section{DAFTAR PUSTAKA}

Aaker, David.A.(1991). Managing Brand Equity: Capitalizing On The Value of A Brand Name. New York: Free Press.

Dirvi Surya Abbas, Arry Eksandy. (2020). The Effect Of Effective Tax Rate, Tunneling Incentive, And Exchange Rate On Company Decisions To Transfer Pricing : Food And Consumption Sub-Sector Companies Listed On The Indonesia Evidence. Palarch's Journal of Archaeology Of Egypt / Egyptology, 17(7), 14430-14442. Retrieved From Https://Archives.Palarch.N1/Index.Php/Jae/Art icle/View/5486

Haryanto, Deny.(2008). Brand Equity: The Way to Boost Your Marketing Performance. Marketing Quotient Community.

Kaputa, Catherine.(2006). U R A Brand! How Smart People Brand Themselves For Business Seccess. America: Davies-Black Publishing

Keller, Kevin Lane.(2008). Strategic Brand Management: Building, measuring, and Managing Brand Equity. New Jersey: Pearson-Prentice Hall.

Malhotra, Naresh. K.(2007). Marketing Research (An Applied Orientation). New Jersey: PearsonPrentice Hall

McNally, David., \& Speak, Karl.D.(2004). Be Your Own Brand.

Mobray, Kaplan.(2009, January). The 10Ks of Personal Branding: Create a Better You (paperback). United States of America: iUniverse.

Montoya, Peter., \& Vandehey, Tim.(2008). The Brand Called You: Make Your Business Stand Out in a Crowded marketplace (paperback). United States of America: McGraw-Hill.

Montoya, Peter Inc. Personal Branding Information. (C) 2003-2006 Peter Montoya, Inc., All Rights Reserved.

http://www.petermontoya.com/mt what is pe rsonal branding/index.asp

Mullins, John .W., Walker, Orville .C, Jr., \& Boyd, Harper.W, Jr.(2008). Marketing Management: A Strategic Decision-Making Approach. New York: McGraw-Hill.

Stobart, Paul.(1994). Brand Power. London: Macmillan 